STATE OF FLORIDA

STATE BOARD OF CONSERVATION

\title{
DIVISION OF GEOLOGY
}

Robert O. Vernon, Director

REPORT OF INVESTIGATIONS NO. 52

RECONNAISSANCE OF THE GROUND-WATER RESOURCES

OF BAKER COUNTY, FLORIDA

By

Gilbert W. Leve

U. S. Geological Survey

Prepared by the

UNITED STATES GEOLOGICAL SURVEY

in cooperation with the

FLORIDA BOARD OF CONSERVATION

DIVISION OF GEOLOGY

Tallahassee, Florida 


\title{
FLORIDA STATE BOARD \\ OF
}

\section{CONSERVATION}

\author{
CLAUDE R. KIRK, JR. \\ Governor
}

TOM ADAMS

Secretary of State

BROWARD WILLIAMS

Treasurer

FLOYD T. CHRISTIAN

Superintendent of Public Instruction
EARL FAIRCLOTH

Attorney General
FRED O. DICKINSON, JR.

Comptroller

DOYLE CONNER

Commissioner of Agriculture

W. RANDOLPH HODGES

Director 


\section{LETTER OF TRANSMITTAL}

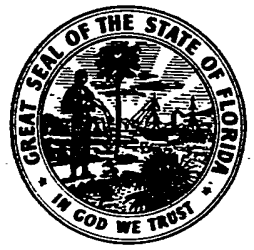

\section{Division of Geology}

Tallahassee

June 4, 1968

Honorable Claude R. Kirk, Jr., Chairman

State Board of Conservation

Tallahassee, Florida

Dear Governor Kirk:

The Division of Geology is publishing as its Report of Investigations No. 52, a report on the "Reconnaissance of the Ground-Water Resources of Baker County, Florida" prepared by Gilbert W. Leve, with the U. S. Geological Survey, as a part of the cooperative investigations of the water resources of Florida-a Division of Geology responsibility.

Ground-water is not widely used in Baker County, but the presence of a high equipotential area in the artesian system beneath the County made it necessary that the resource be understood insofar as this high affected the ground-water resources of Nassau and Duval counties which were being intensively studied and mapped.

The method and rates of movement of ground-water from one point to another in the artesian aquifer are understood more fully by use of the data in this report.

Respectfully yours,

Robert O. Vernon

Director and State Geologist 
Completed manuscript received

June 4, 1968

Published for the Division of Geology

By St. Petersburg Printing Company

St. Petersburg, Florida

1968 


\section{CONTENTS}

Page

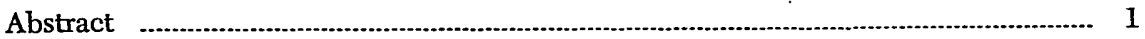

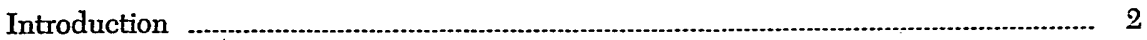

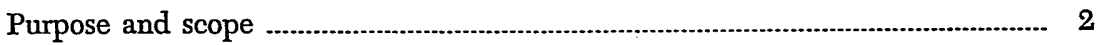

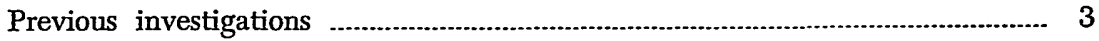

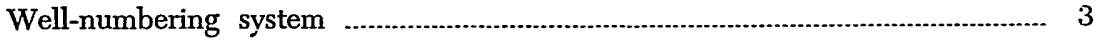

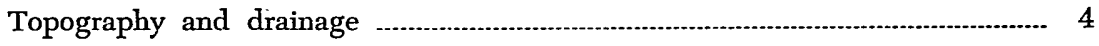

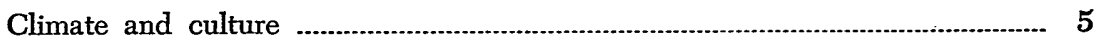

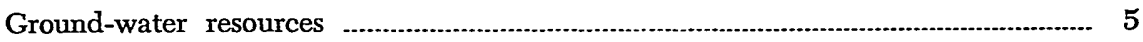

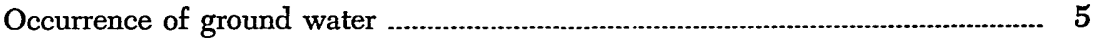

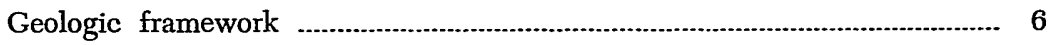

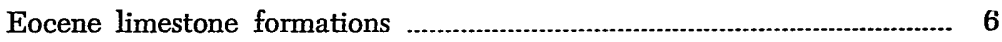

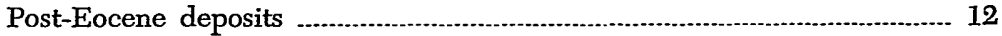

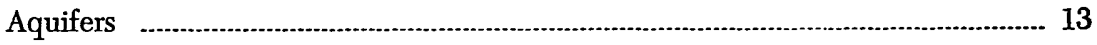

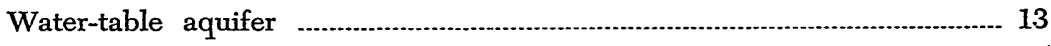

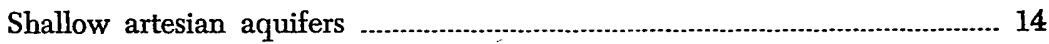

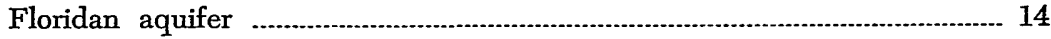

Occurrence and physical characteristics .............................................. 16

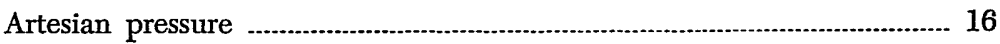

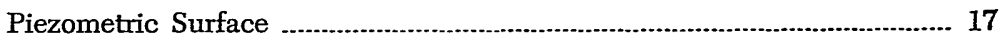

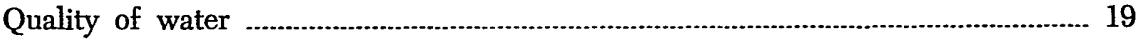

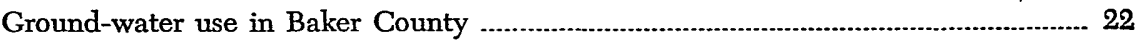

Summary

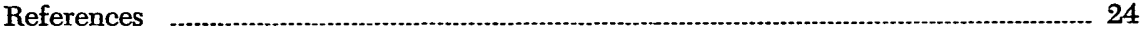




\section{ILLUSTRATIONS}

Figure

Page

1 Map of Baker County, Florida, showing the location of wells....................... 2

2 Diagram illustrating the well-numbering system ......................................... 4

3 Graphs of data collected during the construction of Sanderson test well, 301535N0821620.1

4 Graphs of data collected during the construction of Taylor test well, 302620N0821735.1

5 Map of Baker County showing altitude of the top of the Crystal River Formation

6 Generalized south-north geologic section showing formations penetrated by wells

i Generalized west-east geologic section showing formations penetrated by wells

8 Graphs showing the relation between artesian pressure in Taylor test well, 302620N0821735.1, and rainfall at Glen St. Mary and Lake City

9 Generalized map of the piezometric surface of the Floridan aquifer in northeast Florida, showing greater detail of the piezometric surface in Baker County, March 1964

\section{TABLES}

Table

1 Water levels measured at different depths in test wells 301535N0821620.1, near Sanderson, and 302620N0821735.1, near Tavlor

2 Analyses of water from wells in Baker County 20

3 Records of selected wells in Baker, Duval, and Union Counties. 


\title{
RECONNAISSANCE OF THE GROUND-WATER \\ RESOURCES \\ OF BAKER COUNTY, FLORIDA
}

\author{
By \\ Gilbert W. Leve
}

\section{ABSTRACT}

Baker County comprises approximately 585 square miles in north Florida. The surface of the area is flat with rolling terrain generally between about 100 to 150 feet above sea level which is drained by the St. Marys River and Olustee Creek, a tributary of the Suwannee River. About one-third of the 7,700 inhabitants live in the two major towns of Macclenny and Glen St. Mary.

Water supplies are obtained from three aquifers: (1) the water-table aquifer, (2) the shallow artesian aquifer, and (3) the Floridan aquifer. The greatest potential source of ground water in the county is from the Floridan aquifer. It is composed of limestone formations of Eocene age which underlie all of Baker County at altitudes ranging from less than 50 to more than 350 feet below sea level and are at least 750 to 1,000 feet thick. The Floridan aquifer is recharged to the south of Baker County and possibly in southern Baker County directly by rainfall or by downward percolation from bodies of surface water or shallower aquifers.

Seasonal fluctuations of the artesian pressure in the Floridan aquifer result primarily from changes in the rate of recharge. A progressive decline in the piezometric surface in the Floridan aquifer of 10 to 20 feet from 1945 to 1964 is related in part to increased discharge by wells in adjacent Duval and Nassau counties.

In eastern Baker and Bradford counties, on the eastern flank of the piezometric high, water in the Floridan aquifer moves toward discharge areas in Duval and Nassau counties.

Water from the water-table and shallow artesian aquifers is softer and less mineralized than water from the Floridan aquifer but it contains a higher concentration of iron. The carbonate hardness of water analyzed from wells in the Floridan aquifer ranged from 121 to $204 \mathrm{ppm}$ (parts per million) and the dissolved solids concentration ranged from 141 to $217 \mathrm{ppm}$.

Most rural water supplies are from wells in the water table and shallow artesian aquifers. At present, only the City of Macclenny, the Northeast Florida State Hospital, government installations, and a few private homes obtain water from wells completed in the Floridan aquifer. Large additional quantities of ground water can be developed from the Floridan aquifer to supply forseeable future needs. 


\section{INTRODUCTION}

A reconnaissance investigation of ground water in Baker County, Florida, was conducted as a part of a more comprehensive study of the ground-water resources in adjacent Duval and Nassau counties. Baker County, located in north Florida, is bounded on the east by Nassau and Duval counties; on the south by Clay, Bradford, and Union counties; on the west by Columbia County; and on the north by the State of Georgia, as shown in figure 1 . It is approximately " $L$ " shaped and has an area of about 585 square miles.

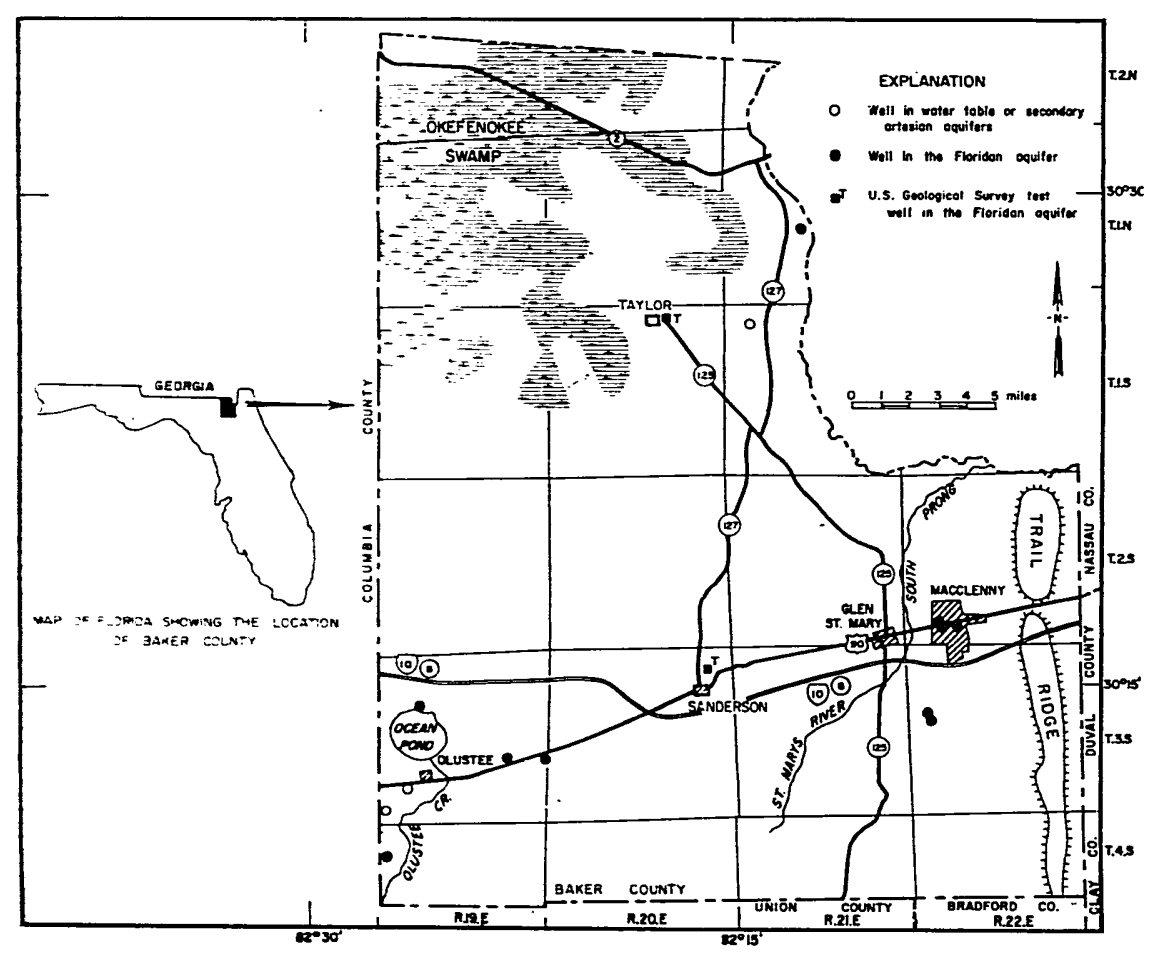

Figure 1. Map of Baker County, Florida, showing the location of wells.

\section{PURPOSE AND SCOPE}

The purpose of this report is to locate and describe the aquifers as an aid to development of the ground-water resources in Baker County and in adjacent and near-by counties of northeast Florida and southeast Georgia.

The investigation was made by the U.S. Geological Survey as part of the statewide cooperative program with the Division of Geology, 
Florida Board of Conservation, to evaluate the water resources of Florida. The report presents and summarizes all of the pertinent, available data on the ground-water resources of Baker County obtained from:

1. Collection of ground-water data by inventorying wells in the county and periodically measuring the water level in selected wells.

2. Collection of geologic information from drillers and in the files of the Division of Geology, Florida Board of Conservation.

3. Drilling of two deep test wells in areas where ground-water data and geologic information were not available.

The investigation was made under the supervision of C. S. Conover, District Chief, Water Resources Division, U.S. Geological Survey.

\section{PREVIOUS INVESTIGATIONS}

No prior investigations have been made of the geology and groundwater resources of Baker County. However, a number of reports by the U.S. Geological Survey and the Division of Geology, Florida Board of Conservation have included general geologic and hydrologic information on the area. Reports by Applin and Applin (1944), Cooke (1945), Vernon (1951), and Puri (1957) include information on the geology of Baker County, and reports by Stringfield (1936, 1966) and Cooper, Kenner, and Brown (1953) include some information on the ground-water resources. The chemical character of water from a number of wells in Baker County is included in a report by Black and Brown (1951). A report by Pride (1958) describes the surface-water resources of Baker County.

\section{WELL-NUMBERING SYSTEM}

The well-numbering system used in this report is that of the Water Resources Division of the U.S. Geological Survey and is based on a one-second grid of parallels of latitude and meridians of longitude, in that order.

The well number is a composite of two numbers separated by the letter $\mathrm{N}$. The first part consists of six digits; the two digits of the degrees, the two digits of the minutes, and the two digits of the seconds of latitude. The $\mathrm{N}$ refers to "north" latitude. The second part consists of seven digits; the three digits of the degrees, the two digits of the minutes, and the two digits of the seconds of longitude. If more than one well lies within a one-second grid, the wells are numbered consecutively and this number is placed at the end of the well number following the decimal. Therefore, the well number defines the latitude and the longitude 
on the south and east sides of a one-second quadrangle in which the well is located.

Figure 2 is a diagram illustrating the well-numbering system. For example, the designation 275134N0815220.1 indicates that this is the

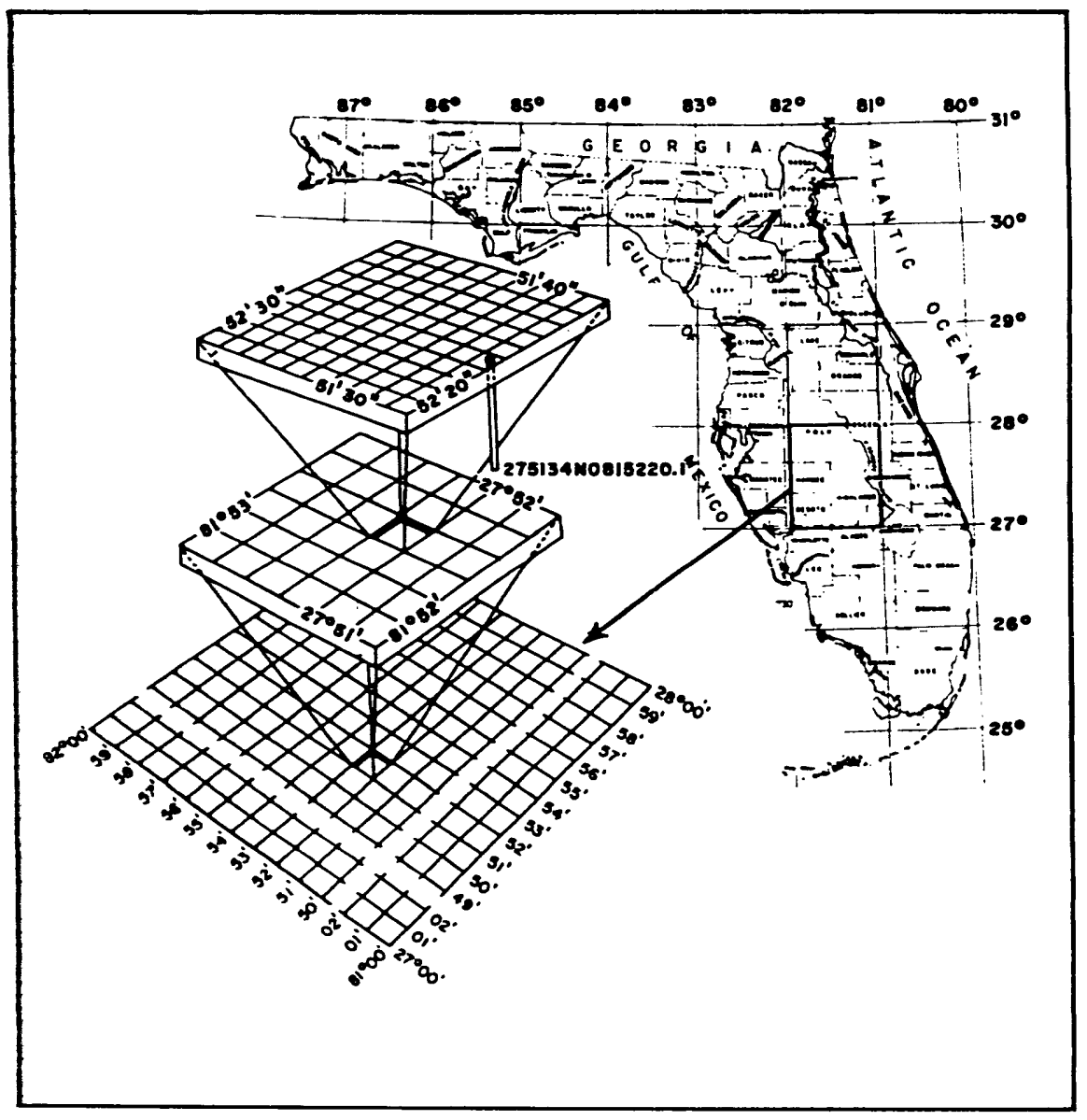

Figure 2. Diagram illustrating the well-numbering system.

first well inventoried in the one-second grid bounded bylatitude $27^{\circ} 51^{\prime} 34^{\prime \prime}$ on the south and longitude $081^{\circ} 52^{\prime} 20^{\prime \prime}$ on the east.

\section{TOPOGRAPHY AND DRAINAGE}

Baker County is in the Central Highlands topographic region (Cooke, 1945, p. 8), and the topography is flat to gently rolling with altitudes 
between about 100 to 150 feet above msl (mean sea level). A high, sandy ridge termed the "Trail Ridge" extends north-south through eastern Baker County. A number of sand hills on this ridge have altitudes of more than 200 feet.

Most of the surface drainage is by the St. Marys River and its tributaries. Small areas in western and southern Baker County are drained by Olustee Creek, a tributary of the Suwannee River. Streams are sluggish and poorly developed on the flat terrain and much of the area is marshland. The Okefenokee Swamp, which occupies a large area in southern Georgia, extends into northern Baker County.

\section{CLIMATE AND CULTURE}

The climate of Baker County is subtropical. The average annual temperature is about $69^{\circ} \mathrm{F}$, and the average annual rainfall is about 52 inches. Most of the rain occurs during the summer months. Rainfall of more than 10 inches per month during the summer and less than half an inch per month during the late fall is not uncommon.

According to the 1960 U.S. Census, the population of Baker County was 7,400; and, in 1965, it was estimated to be about 8,000 by the Bureau of Economic and Business Research, University of Florida. About onethird of the population lives in the major towns of Macclenny and Glen St. Mary. The major industries are lumbering, wood pulp, and cattle ranching. Two large nurseries at Glen St. Mary, a number of small farms, and the Northeast Florida State Mental Hospital add to the economy of the county.

\section{GROUND-WATER RESOURCES}

Water supplies in Baker County are available from both surface- and ground-water sources. However, surface-water sources are undependable because of droughts; and they generally are too far from the water users to be economically used. The surface-water resources of the county are discussed in a report by Pride (1958). Practically all water presently used in the county is ground water. This report discusses only the ground-water resources in the area.

\section{OCCURRENCE OF GROUND WATER}

Rain is the source of most ground water. Part of the rain is returned to the atmosphere by evapotranspiration, part drains overland into lakes and streams, and part seeps into the ground near the point where it falls, or also from lakes and streams. Only the water that reaches the 
zone of saturation-the zone saturated with water under hydrostatic pressure-becomes ground water.

The occurrence of ground water is controlled primarily by the subsurface rocks. The chemical composition, physical characteristics, and structure of the geologic formations determine the quality of the ground water, the amount of water available, and the vertical and areal distribution of ground water. In order to obtain information on the subsurface rocks in Baker County, logs of wells and cuttings obtained from wells on file with the Division of Geology, Florida Board of Conservation were examined. Also, two test wells were drilled in areas where geologic or ground-water information was lacking.

\section{GEOLOGIC FRAMEWORK}

The geologic framework that controls the occurrence and distribution of ground water in Baker County is graphically portrayed by the logs of the two test wells, figures 3 and 4, the map of the top of the Crystal River Formation, figure 5, and the geologic sections, figures 6 and 7 . Although the chemical composition and the physical properties of the geologic formations may vary slightly throughout the county, the type of rocks penetrated by the test wells are essentially typical of the subsurface rocks underlying the entire county. Both wells were drilled into the Lake City Limestone, which is the deepest formation generally penetrated by water wells in northeastern Florida and southeastern Georgia.

\section{EOCENE LIMESTONE FORMATIONS}

The oldest formation shown in figures 3-7 is the Lake City Limestone of middle Eocene age. It is predominantly a tan to dark brown, hard, massive, dolomitic limestone and medium soft, finely crystalline dolomite, both containing relatively thin beds of tan, soft, chalky to granular limestone. The Lake City Limestone is about 500 feet thick and its top ranges from about 450 feet below sea level in the southwestern part of the county to more than 650 feet below sea level in the eastern part.

The Avon Park Limestone of late middle Eocene age unconformably overlies the Lake City Limestone and is similar in lithology. It is about 140 feet thick in southwestern Baker County and thins to less than 50 feet in the eastern part of the county. The top of the formation ranges from 300 feet below sea level in southwestern Baker County to more than 600 feet below sea level in the eastern part. 


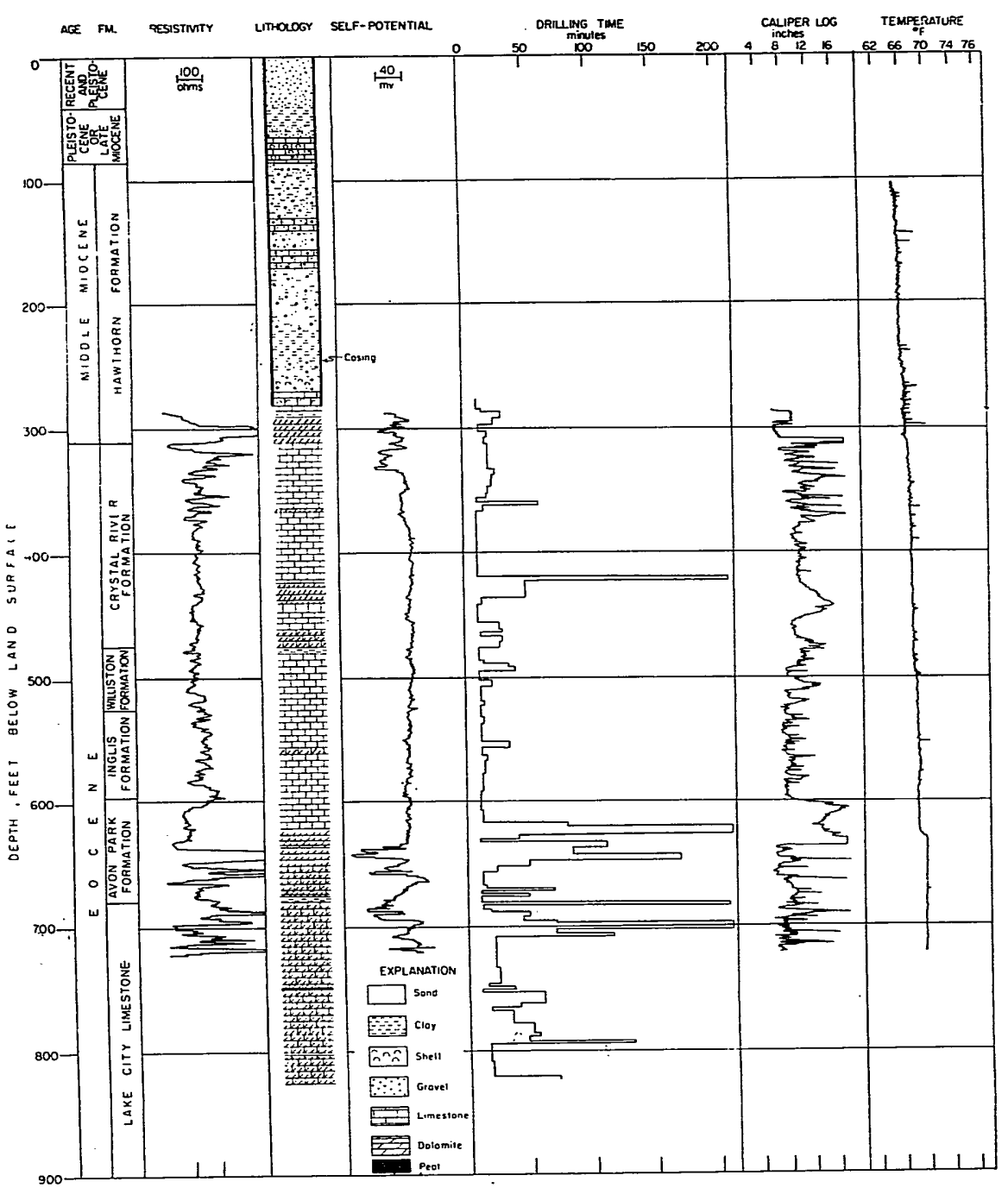

Figure 3. Graphs of data collected during the construction of Sanderson test well, 301535N0821620.1

The Ocala Group ${ }^{1}$, Inglis, Williston, and Crystal River Formations of late Eocene age consist of a relatively homogeneous sequence of cream to light gray, medium soft, chalky to granular, marine limestone, containing thin beds of hard, massive, dolomitic limestone and dolomite.

${ }^{1}$ The classification and nomenclature of the rock units conform to the usage of the Division of Geology, Florida Board of Conservation and, also, except for the Ocala Group and its subdivisions, with those of the U. S. Geological Survey, which regards the Ocala as two formations, the Ocala Limestone and the Inglis Limestone. 


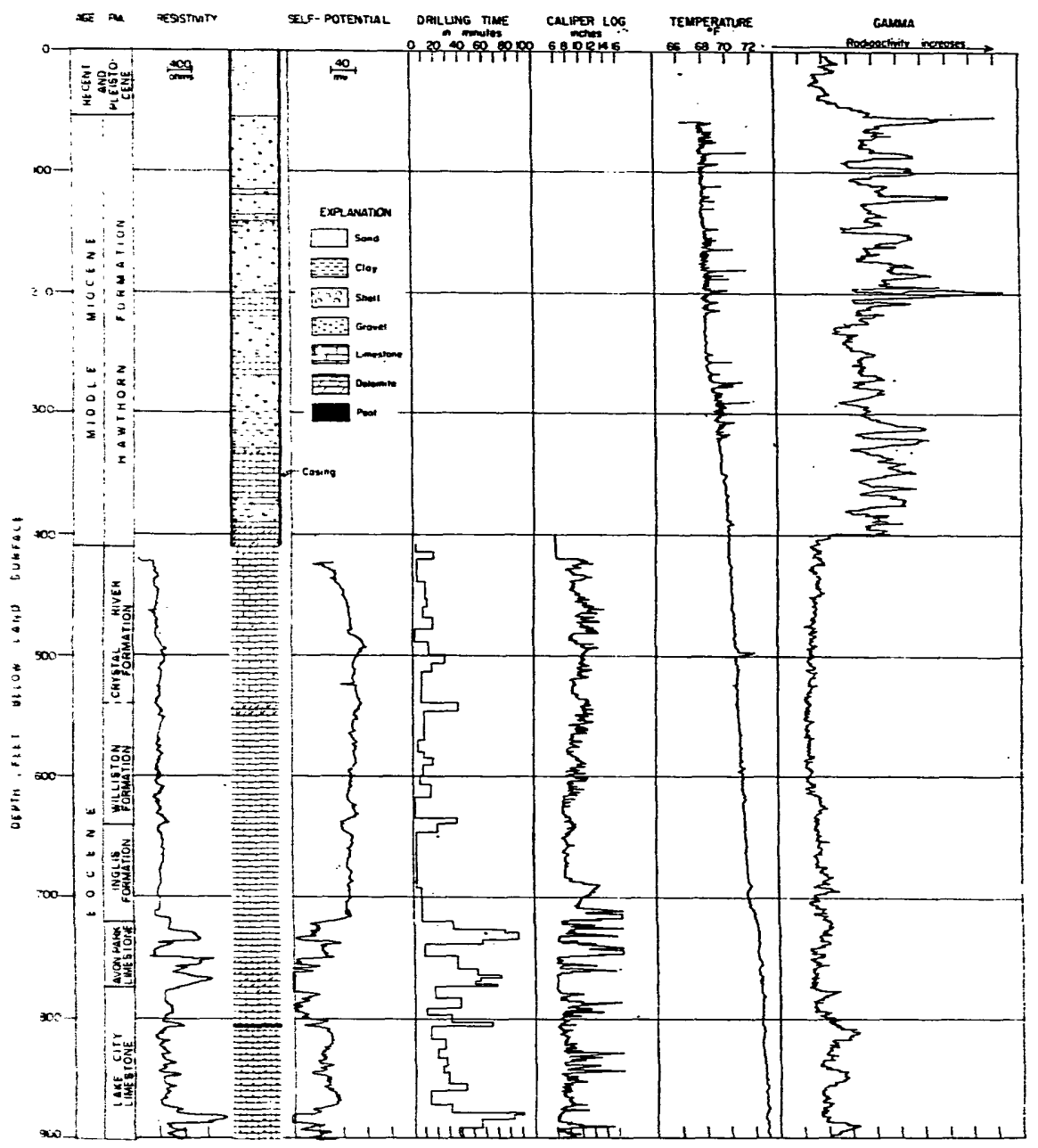

Figure 4. Graphs of data collected during the construction of Taylor test well, 302620N0821735.1

The Inglis and Williston Formations are generally more granular in texture than the overlying Crystal River Formation and the Inglis Formation generally is more calcitic and slightly darker in color than either the Williston or the Crystal River Formations.

The geologic sections in figures 6 and 7 show that the thickness of the Ocala Group ranges from about 220 to 310 feet in Baker County. The average thickness of the Crystal River Formation is about 150 feet and the average thickness of the Williston and Inglis Formations is about 50 feet each. 


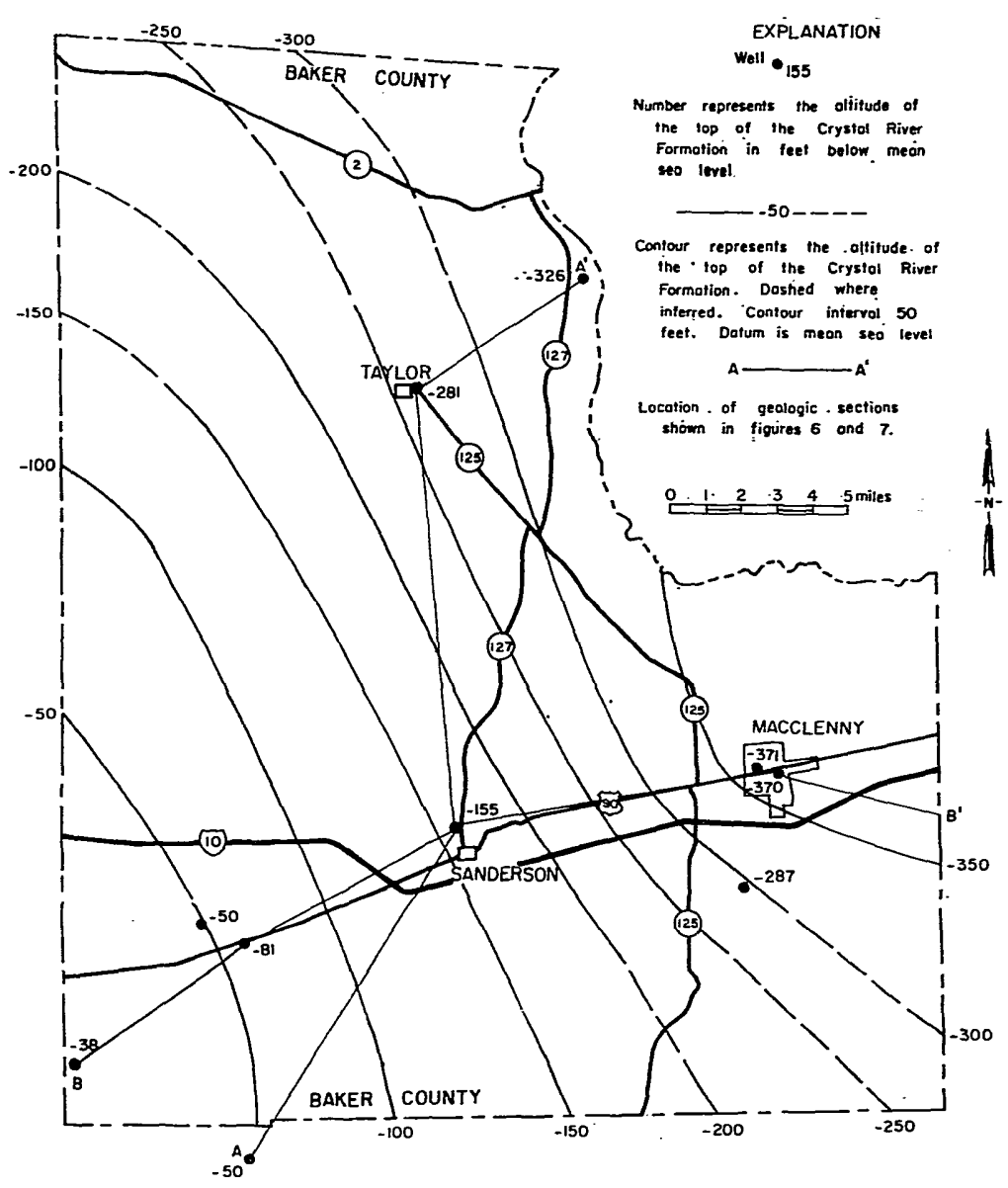

Figure 5. Map of Baker County showing altitude of the top of the Crystal River Formation.

The altitude and configuration of the top of the Crystal River Formation are shown by contour lines in figure 5 . The top of the Crystal River Formation ranges from about 50 feet below sea level in southwestern Baker County to about 350 feet below sea level in the eastern part. Structurally, the surface of the Crystal River Formation in Baker County is a monocline which strikes approximately north-northwest-south-southeast and dips east-northeastward about 20 feet per mile. 


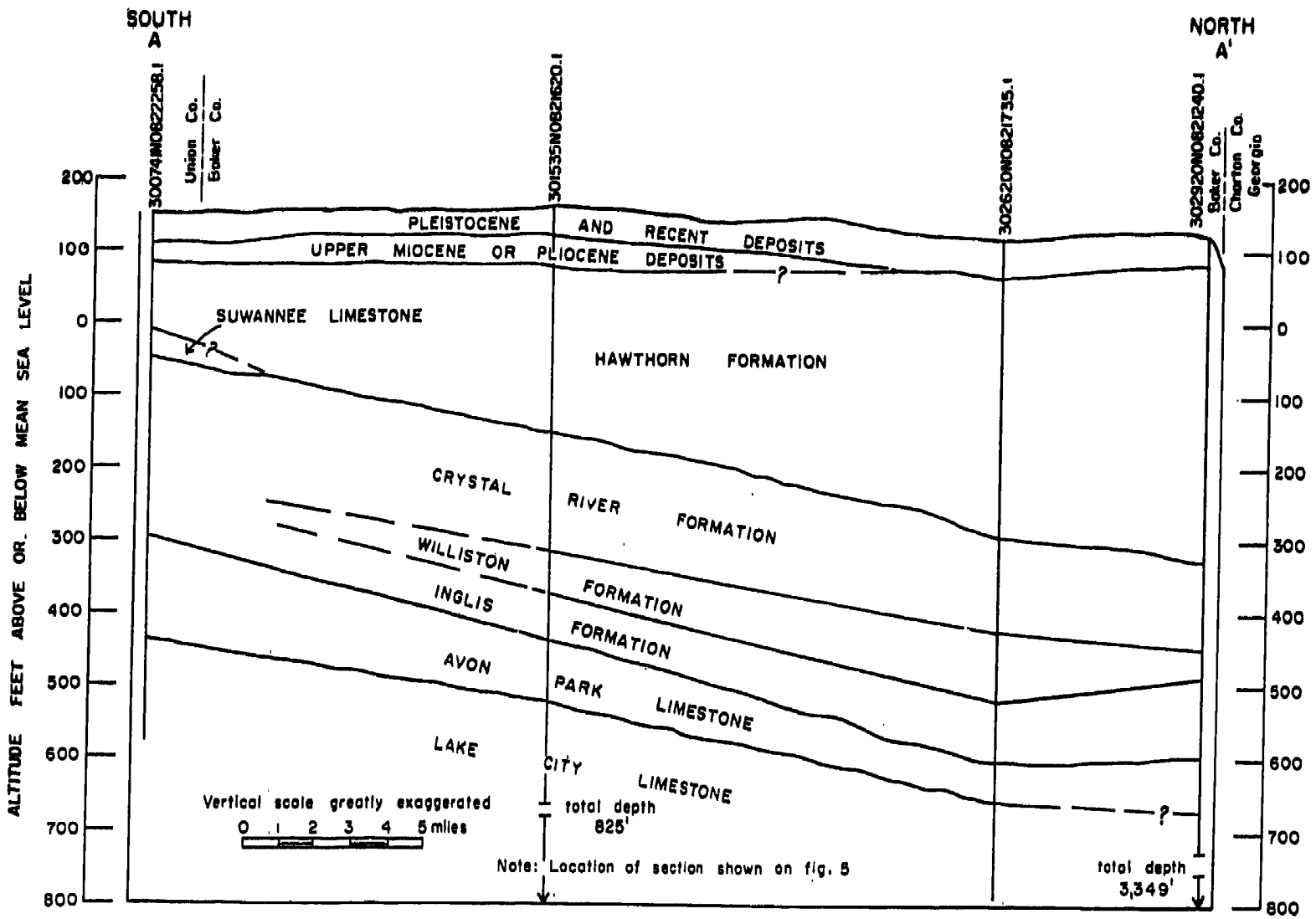

Figure 6. Generalized south-north geologic section showing formations penetrated by wells. 


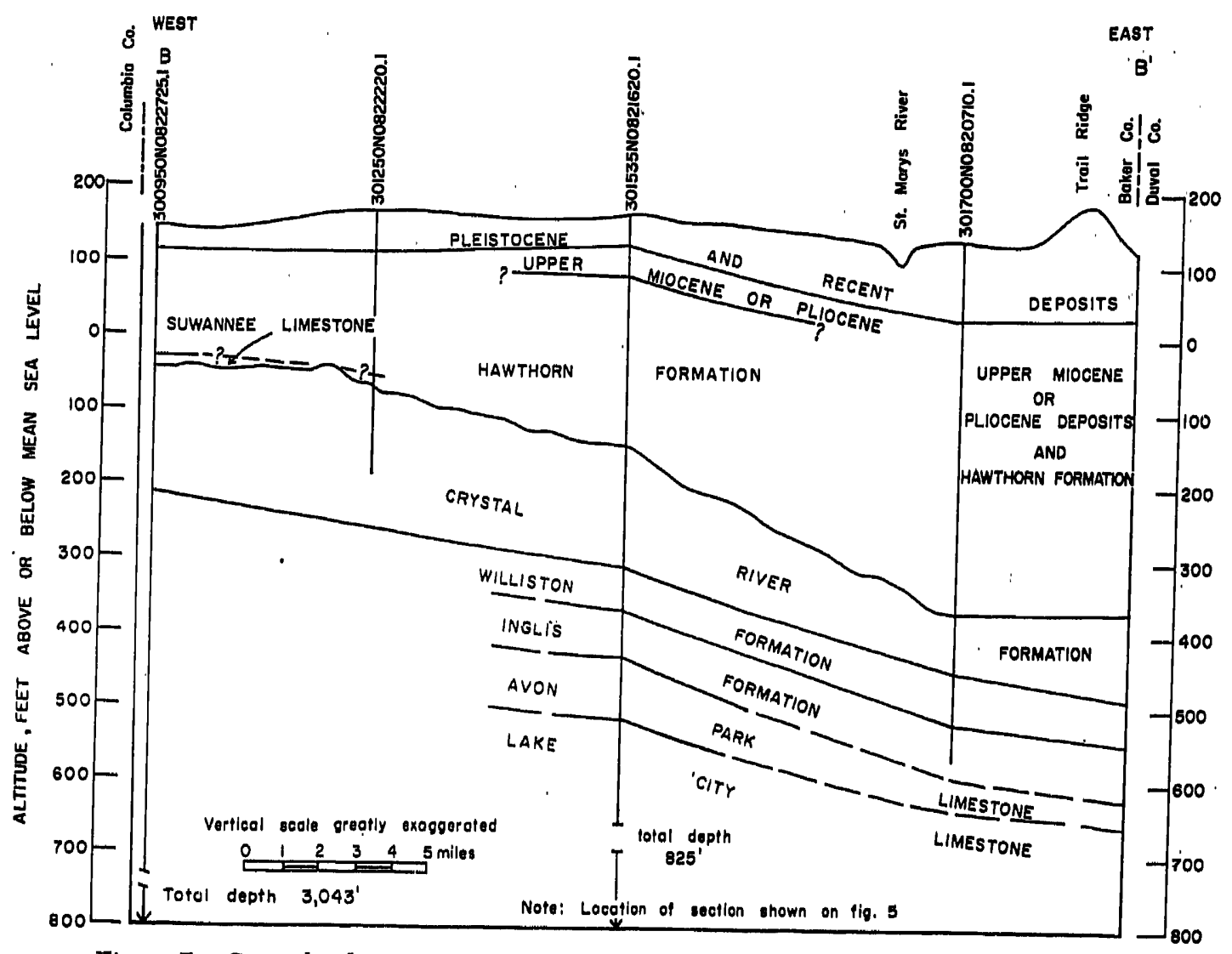

Figure 7. Generalized west-east geologic section showing formations penetrated by wells. 


\section{POST-EOCENE DEPOSITS}

In southwestern Baker County, the Crystal River Formation is overlain by the Suwannee Limestone of late Oligocene age. It consists of light gray to white, granular, limestone and yellowish brown, indurated, siltstone and sandstone cemented with calcium carbonate. As shown on the geologic cross sections in figure 5 , the Suwannee Limestone is less than 30 feet thick in southwestern Baker County. It was not recognized in cuttings from either of the test wells in central Baker County or in cuttings from wells in the eastern part. The Suwannee Limestone either was not deposited in these areas or it was removed by erosion prior to the deposition of the Hawthorn Formation.

Where the Suwannee Limestone is absent, the Crystal River Formation is overlain by the Hawthorn Formation of middle Miocene age. The Hawthorn Formation consists of gray to olive green, phosphatic, clayey sand and sandy clay; gray to green, phosphatic, calcareous clay, interbedded with lenses of medium to coarse, phosphatic sand; and phosphatic, sandy limestone, shell and dolomite. The dolomite beds generally occur near the base of the formation and are about 20 feet thick in both of the test wells. Examination of the cuttings from a number of wells in the county show the Hawthorn Formation is overlain by beds of green, calcareous, shelly clay; white, granular limestone; and fine to medium sand. These overlying deposits are similar to those in the Hawthorn Formation but they contain no phosphate and more shells. They can be correlated to the upper Miocene or Pliocene deposits in neighboring Nassau and Duval counties (Leve, 1966) on the basis of lithology and position in the subsurface. As shown on the geologic sections, figures 6 and $\bar{\tau}$, the combined thickness of the Hawthorn Formation and the upper Miocene or Pliocene deposits range from about 120 feet in western Baker County to about 400 feet in the eastern part.

Deposits of Pleistocene and Recent age overlie the upper Miocene or Pliocene deposits and the Hawthorn Formation and blanket the surface of Baker County. Undifferentiated beds of fine to coarse sand and green to red, silty clay were deposited as marine terraces by fluctuations of the sea level during Pleistocene interglacial periods. Recent sediments are presently being deposited as alluvial sand and clay in the stream valleys and as peat and muck in the lakes, swamps, and other poorly drained areas in the county. The deposits of Pleistocene and Recent age are discontinuous and vary in texture and lithology within short distances both laterally and vertically. The combined thickness of these deposits ranges from about 30 feet in western Baker County to about $\mathbf{1 5 0}$ feet in the vicinity of Trail Ridge in the eastern part. 


\section{AQUIFERS}

Rocks that are sufficiently permeable to yield usable quantities of water to wells are called aquifers. The aquifers serve as conduits that distribute and store ground water. Where the aquifer is not overlain by an impermeable bed and the surface of the water is free to rise and fall, it is termed a water-table aquifer. Where the aquifer is overlain by an impermeable bed and the water in the aquifer is confined under pressure, it is termed an artesian aquifer. Both water-table and artesian aquifers occur in Baker County.

\section{WATER-TABLE AQUIFER}

The water-table aquifer occurs in upper Miocene or Pliocene deposits and Pleistocene and Recent deposits which together range in thickness from about 30 feet in western Baker County to more than 150 feet. Permeable sand and shell beds within about the uppermost 50 feet of these deposits comprise the aquifer; however, these permeable beds are discontinuous and wedge out laterally against less permeable silty clay beds. Generally, wells completed less than 30 feet deep, in the surficial sand beds, will tap part or all of the water-table aquifer.

The water-table aquifer is recharged principally by local rainfall and from surface streams and marshes. Water discharges from the water-table aquifer by evapotranspiration, by seepage into streams, lakes, and swamps when their water surface is lower than the water level in the aquifer, by downward percolation into deeper aquifers, and by pumpage from a few wells.

The water level in the water-table aquifer rises when the amount of recharge exceeds the rate of discharge and vice versa. Seasonal fluctuations of the watel level of 6 to 8 feet are not uncommon, and some wells completed in the upper part of the aquifer go dry when the water levels decline and have to be deepened. In addition, centrifugal pumps installed on some wells during periods of relatively high water levels fail when the water levels are relatively low and have to be replaced with deep-well pumps.

Water from the water-table aquifer is relatively high in iron content which stains plumbing fixtures and imparts a bad taste to the water. The high iron content of the water combined with the seasonal declines of water levels make this aquifer the least desirable source of ground water in the county. However, a number of rural domestic, stock, and irrigation supplies are obtained from this aquifer because of the relatively inexpensive cost. 


\section{SHALLOW ARTESIAN AQUIFERS}

The shallow artesian aquifers in Baker County consist of relatively thin, discontinuous lenses of sand, shell, and limestone within relatively impermeable beds of clay and clayey sand in the Hawthorn Formation and in the upper Miocene or Pliocene deposits. The relatively impermeable beds restrict the vertical movement of water and confine the water under artesian pressure within the aquifers. Similar conditions exist at places within the Pleistocene and Recent deposits during certain times of the year when the aquifer is completely saturated.

The occurrence of shallow artesian aquifers varies throughout Baker County and the exact depth and thickness of the aquifers at any location often cannot be predetermined. In test well 301535N0821620.1, near Sanderson (fig. 3), shallow artesian aquifers were located at depths of 70 to 90 feet below land surface near the base of the upper Miocene or Pliocene deposits and from 130 to 140 feet below land surface and from 160 to 180 feet below land surface in the Hawthorn Formation. In test well 302620N0821735.1, near Taylor (fig. 4), shallow artesian aquifers were located at depths from 200 to 220 feet below land surface, from 255 to 270 feet below land surface, and from 330 to 380 feet below land surface in the Hawthorn Formation.

The artesian pressure in shallow artesian aquifers differs depending on the areal location within the county and the depth of each aquifer. Table 1 shows the water level measured at different depths in test wells 301535N0821620.1 and 302620N0821735.1. The water levels in each of the shallow artesian aquifers are lower than the water level in the water-table aquifer and higher than the water level in the Floridan aquifer.

The shallow artesian aquifers are recharged locally by downward seepage of water from the water-table aquifer.

Wells completed in the shallow artesian aquifers generally yield more water with a lower iron content than wells completed in the water-table aquifer. Small-diameter wells throughout Baker County produce water from these aquifers for domestic, stock, and irrigation supplies.

\section{FLORIDAN AQUIFER}

The Floridan aquifer is the principal source of water supplies in northeastern Florida and southeastern Georgia; and, although it is presently tapped by only a few wells in Baker County, it is the greatest potential source of water supplies in the area. Development of water supplies from the aquifer in one part of the area could eventually affect hydrologic conditions over the entire area. Therefore, knowledge of the 
Table 1. WATER LEVELS MEASURED AT DIFFERENT DEPTHS IN TEST

WELLS 301535N0821620.1, NEAR SANDERSON, AND 302620N0821 735.1, NEAR TAYLOR

\begin{tabular}{|c|c|c|c|c|c|c|c|}
\hline \multicolumn{4}{|c|}{$\begin{array}{l}\text { Well 301535N0821620.1 } \\
\text { Depth, feet below land surface }\end{array}$} & \multicolumn{4}{|c|}{$\begin{array}{l}\text { Well } 302620 \text { N0821735.1 } \\
\text { Depth, feet below land surface }\end{array}$} \\
\hline Casing & Hole & $\begin{array}{l}\text { Water } \\
\text { Level }\end{array}$ & Aquifer & Casing & Hole & $\begin{array}{l}\text { Water } \\
\text { Level }\end{array}$ & Aquifer \\
\hline 20 & 20 & $10-12$ & $\begin{array}{l}\text { Water table } \\
0.40\end{array}$ & 46 & 50 & 17 & $\begin{array}{c}\text { Water table } \\
0.55\end{array}$ \\
\hline 83 & 83 & 14.5 & $\begin{array}{l}\text { Sec. artesian } \\
70-90\end{array}$ & 185 & 208 & 21 & $\begin{array}{l}\text { Sec. artesian } \\
200-220\end{array}$ \\
\hline 165 & 174 & 20.9 & $\begin{array}{l}\text { Sec. artesian } \\
160-180\end{array}$ & 230 & 245 & 18.8 & $\begin{array}{l}\text { Sec. artesian } \\
255-270\end{array}$ \\
\hline 282 & 335 & 99 & & 334 & 370 & 57.8 & $\begin{array}{l}\text { Sec. artesian } \\
330-380\end{array}$ \\
\hline 282 & 425 & 100.7 & $\begin{array}{l}\text { Floridan } \\
315-825\end{array}$ & 416 & 450 & 60 & \\
\hline 282 & 810 & 100.5 & & $\begin{array}{l}416 \\
416\end{array}$ & $\begin{array}{l}472 \\
905\end{array}$ & $\begin{array}{l}62.1 \\
60.9\end{array}$ & $\begin{array}{l}\text { Floridan } \\
409-905\end{array}$ \\
\hline
\end{tabular}


characteristics of the Floridan aquifer in Baker County would aid future development of the aquifer in adjacent areas.

\section{OCCURRENCE AND PHYSICAL CHARACTERISTICS}

The Floridan aquifer in Baker County consists primarily of permeable limestone and dolomite beds of Eocene age. Locally, however, the Suwannee Limestone of late Oligocene age and limestone beds in the Hawthorn Formation of middle Miocene age form part of the aquifer. The aquifer underlies all of the county; and, as shown in figure 5, the top of the aquifer ranges from less than $\mathbf{5 0}$ feet below sea level in the western part to more than 350 feet in the eastern part. The exact thickness of the aquifer is not known; however, it is more than 1,600 feet thick in southwestern Baker County and about 1,900 feet thick in the northeastern part. Most water wells penetrate less than 1,000 feet of the aquifer.

The permeable limestone and dolomite formations contain dense zones, occurring primarily in the Avon Park and Lake City Limestones, that are relatively impermeable and restrict the vertical movement of water within the aquifer. Possibly some of these zones are extensive laterally and may separate water-producing zones within the aquifer such as occur in adjacent Duval and Nassau counties (Leve, 1964).

\section{ARTESIAN PRESSURE}

Water in the Floridan aquifer is confined under pressure by poorly permeable sandy clays in the overlying Hawthorn Formation and in the upper Miocene or Pliocene deposits. In north-central Florida, the aquifer is recharged primarily in areas where the confining beds are thin, absent, or where they are breached by streams and sinkholes and water moves downward into the aquifer. Water is discharged from the Floridan aquifer, by upward seepage, and through wells.

Artesian pressure in the Floridan aquifer continuously fluctuates, and most significant changes are those caused by recharge and discharge. When the rate of recharge exceeds the rate of discharge over a significant period of time, artesian pressures increase and vice versa.

Artesian pressure can be expressed as the altitude above a fixed datum to which water will rise in a tightly cased well. Figure 8 shows the relation between artesian pressure in well 302620N0821735.1 and rainfall at Glen St. Mary and Lake City for the period from December 1963 through February 1964. As shown, an increase in rainfall from 2.8 inches in December to 9.2 inches in January resulted in about a 3-foot rise in artesian pressure. The artesian pressure increased only 1 foot during February because of a decrease in the amount of rainfall during the month. 

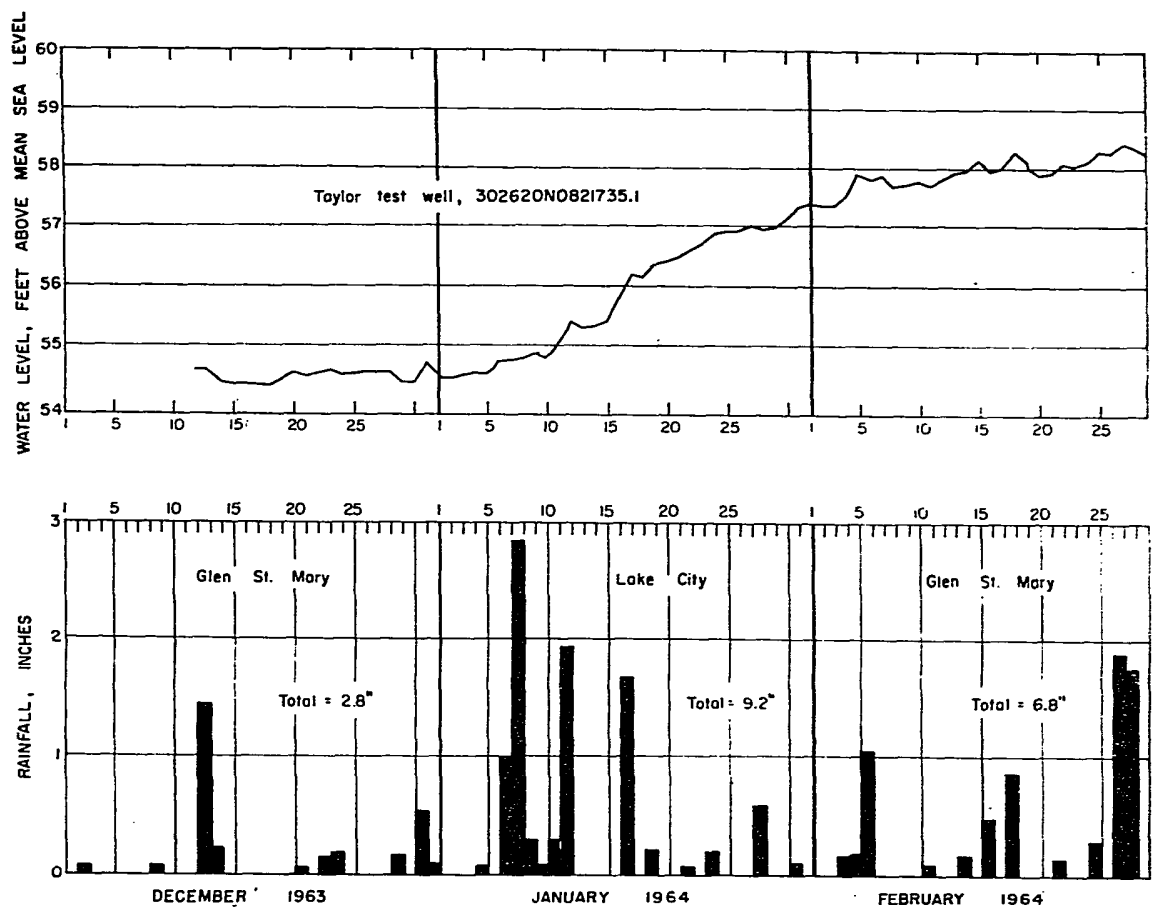

Figure 8. Graphs showing the relation between artesian pressure in Taylor test well, 302620N0821735.1, and rainfall at Glen St. Mary and Lake City.

\section{PIEZOMETRIC SURFACE}

The piezometric surface is an imaginary surface to which water from an aquifer will rise in tightly cased wells that penetrate the aquifer. The piezometric surface is shown by contour lines that connect points of equal altitude. Generally, water enters the aquifer in those areas where piezometric surface is high and moves downgradient in a direction approximately perpendicular to the contour lines. The velocity of the ground-water movement depends on the permeability of the aquifer and the hydraulic gradient. Piezometric maps can also be used to determine the rate of ground-water flow if the permeability and thickness of the aquifer are known.

Figure 9 shows the piezometric surface of the Floridan aquifer in Baker County and adjacent areas in March 1964. The piezometric high as shown is the northern extension of a high that centers in Alachua, Clay, and Putnam counties. The configuration of the piezometric surface in figure 9 indicates that water enters the Floridan aquifer south of Baker County and possibly within southern Baker County and moves radially away. 


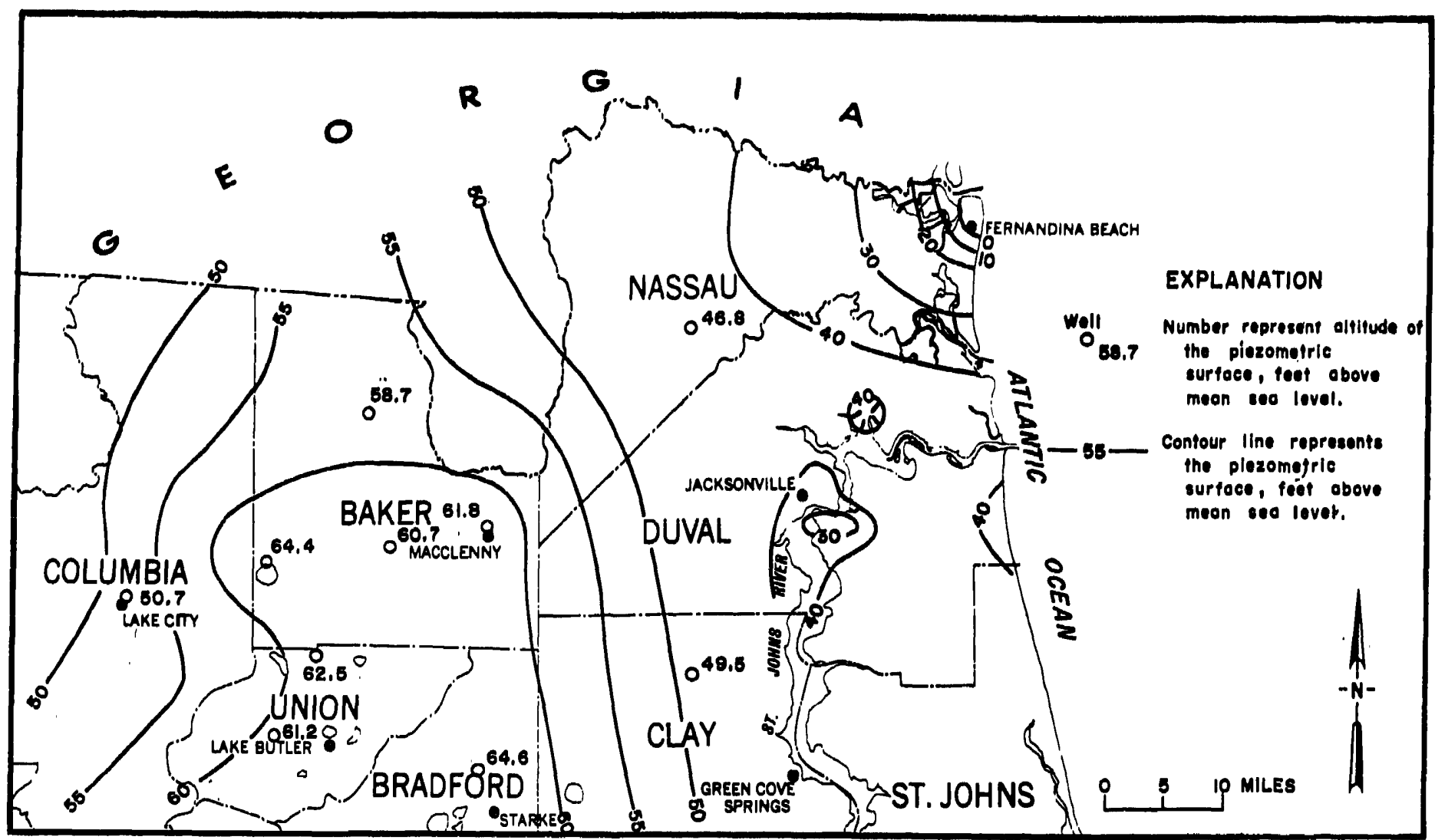

Figure 9. Generalized map of the piezometric surface of the Floridan aquifer in northeast Florida, showing greater detail of the piezometric surface in Baker County, March 1964. 
Much of the ground water that moves eastward in the Floridan aquifer from the piezometric high is discharged in areas in Duval and Nassau counties where large quantities of water are used by industries and cities.

\section{QUALITY OF WATER}

Rainfall entering the ground is only slightly mineralized. As the water moves through the ground, it dissolves some of the minerals that compose the rocks. Therefore, the chemical quality of ground water is primarily a result of the dissolution of minerals in the rocks through which it moves.

Table 2 lists analyses of water from selected wells in Baker County. Water in the water-table and shallow artesian aquifers is generally softer and less mineralized than water in the Floridan aquifer but has a higher iron content. As shown on table 2, water from well 301220 N0822630.1, which taps the water-table or a shallow artesian aquifer, contains only $27 \mathrm{ppm}$ dissolved solids. This mineral content is considerably lower than in water from the Floridan aquifer; however, the water contains $1.8 \mathrm{ppm}$ of iron (over $0.3 \mathrm{ppm}$ of iron is considered excessive).

Water in the Floridan aquifer is of similar chemical quality throughout Baker County. As shown in table 2, the dissolved solid content ranges from 141 to $217 \mathrm{ppm}$; and the carbonate hardness ranges from 121 to $204 \mathrm{ppm}$. Analyses of water samples collected several years apart indicate a slight, but probably insignificant, increase in the content of water in the aquifer has occurred in recent years.

The temperature of water at different depths in the Floridan aquifer was determined in test wells at Sanderson and Taylor. As shown by graphs in figures 3 and 4 , the temperature of the water increased from $66 \%^{\circ}$ at the top of the aquifer to $69^{\circ} \mathrm{F}$ at the bottom of the well or an increase of about $2{ }^{1}{ }^{\circ} \mathrm{F}$ in about 400 feet in the well at Sanderson, and it increased from $70^{\circ} \mathrm{F}$ at the top of the aquifer to $73^{\circ} \mathrm{F}$ at the bottom of the well or an increase of about $3^{\circ} \mathrm{F}$ in 500 feet in the well at Taylor. This represents an increase of about $1^{\circ} \mathrm{F}$ for every 160 feet penetration in the Floridan aquifer. A slight but pronounced temperature anomaly was recorded at 500 feet below land surface in the well at Taylor which may indicate the presence of a highly mineralized zone.

Water from the Floridan aquifer in Baker County, except for being relatively hard, is of good quality and may be used for domestic, agricultural, and most industrial purposes.

Records of selected wells in Baker, Duval, and Union counties are presented in table 3 . 
Table 2. ANALYSES OF WATER FROM WELLS IN BAKER COUNTY.

(Chemlcal constituents are expressed in parts per million)

Aquifer: F, Floridan; SA, secondary artesian; WT, water table.

Remarks: Analysts: (1) Fla. Board Health; (2) Univ. of Fla,; (3) Black Lab-Gainesville.

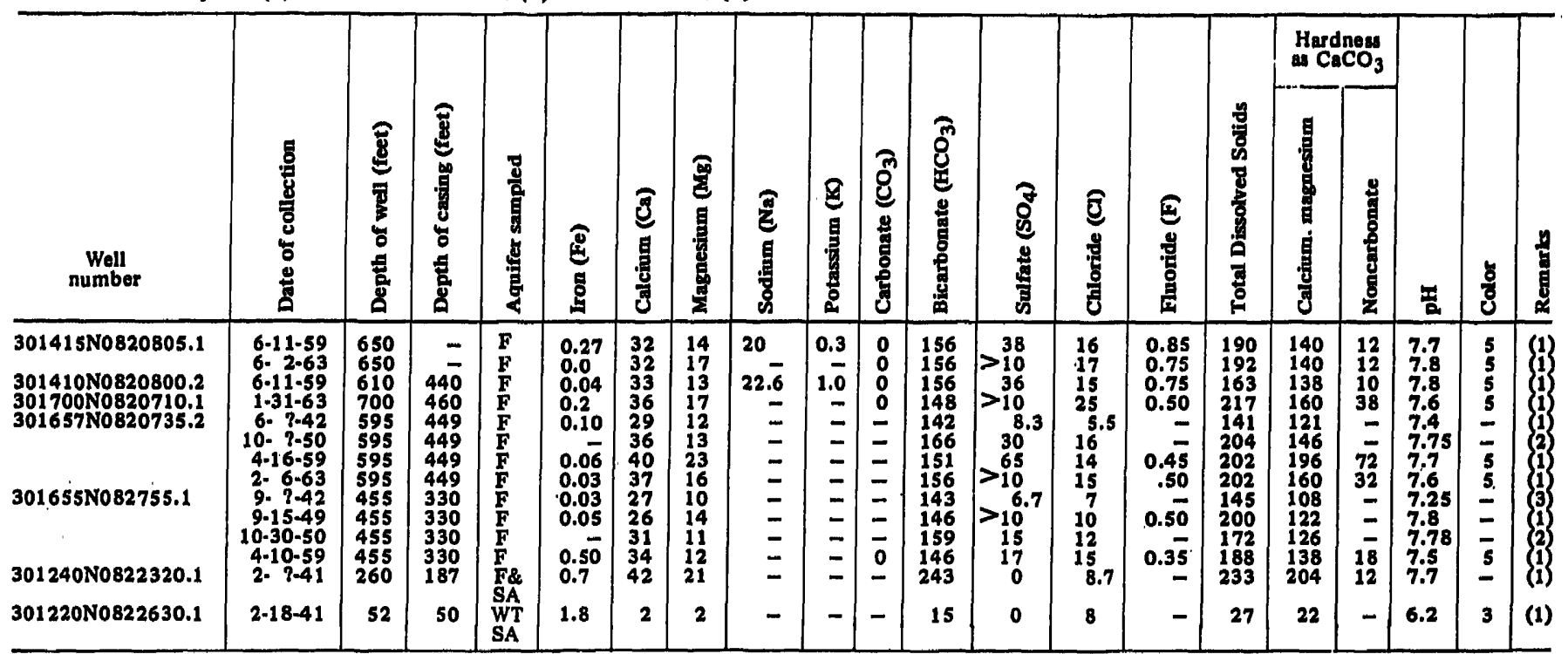


Table 3. RECORDS OF WELLS IN BAKER, DUVAL AND UNION COUNTIES.

WELL NUMBERS: See Figure 2 for explanation of well-numbering system.

OWNERSHIP: C, county; F, Federal government; M, city; N, company or corporation; $\mathrm{S}$, State agency.

DEPTH OF WELL: To nearest foot.

WELL FINISH: $X$, open hole in aquifer, cased to aquifer; $Z$, gravel pack. METHOD DRILLED; $\mathrm{C}$, cable-tool; $\mathrm{H}$, hydraulic rotary; J, jetted.

TYPE PUMP: $J$, jet; $N$, none; $T$, turbine.

USE OF WATER: H, domestic; I, irrigation; P. municipal or public supply; $U$, unused.
AQUIFERS: $1 F$, Floridan; $2 \mathrm{H}$, Hawthorne-clayey sand and gravel; $1 \mathrm{M}$, Miocene-limestone; $1 \mathrm{~N}$, Nonartesian sand aquifer.

ALTITUDE OF LAND SURFACE: To the nearest foot above mean sea level.

WATER LEVEL: To the nearest foot. Date of measurement includes month and year.

CHEMICAL ANALYSES AVAILABLE: C, complete; $P$, partial

RANGE OF CHEMICAL CONSTTTUENTS: Iron: $0,0.00-0.05 ; 1$, $0.06-0.1 ; 2,0.11-0.30 ; 5,1.1-3.0$. Sulfate: $0,0-10 ; 2,26-50 ; 3$ 51-100. Chloride: 0, 0-10, 1, 11-25; Hardness: 2, 21-50; 4, 101-150; $5,151-200$.

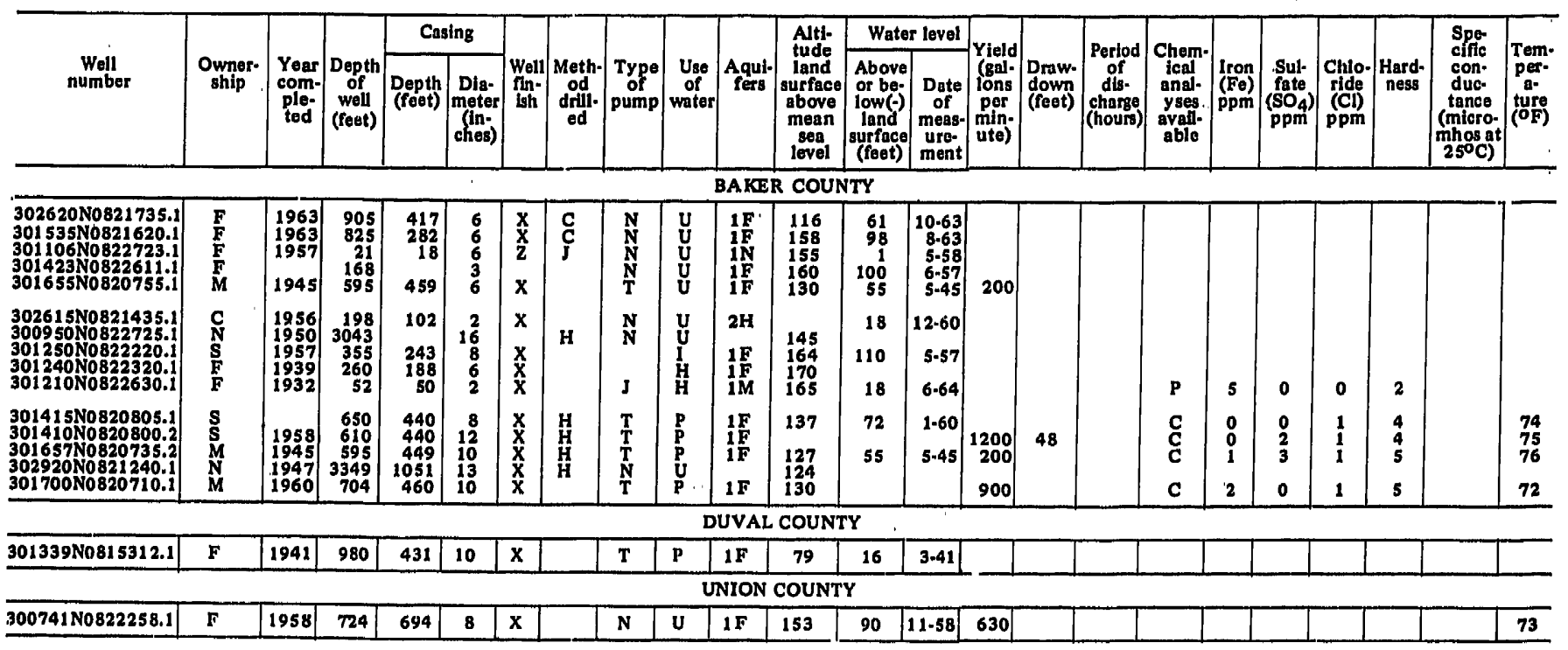




\section{GROUND-WATER USE IN BAKER COUNTY}

Because the water-table and shallow artesian aquifers occur at relatively shallow depths throughout Baker County, water supplies from these aquifers can be developed economically. Most rural farm homes have wells, generally two inches in diameter, developed in these aquifers which furnish the small to moderate amounts of water needed for domestic and stock use.

Large supplies of ground water for municipal, industrial, or irrigation use in Baker County can be obtained from the Floridan aquifer. In 1966, only a few wells were drilled into the Floridan aquifer because of the lack of need of large quantities of water required by industries. Only one municipal supply existed and obtained its water from the Floridan aquifer. The following are large users of water from the Floridan aquifer:

City of Macclenny-Water is obtained from two wells that are 10 inches in diameter and 595 and 700 feet deep with an emergency standby well 455 feet deep. The water is pumped from the wells to a treatment plant with a rated capacity of about $1 \mathrm{mgd}$. Municipal water use has increased from about 130,000 gpd in 1950 to about 250,000 gpd in 1963.

Northeast Florida State Hospital-This hospital, about three miles south of Macclenny, is supplied with water from the Floridan aquifer by two wells that are 8 inches in diameter and 610 and 650 feet deep respectively. The water is pumped to a treatment plant and then to the hospital and to a number of homes of personnel connected with the hospital in the area. Water use increased from about 90,000 gpd in 1959 to about 195,000 gpd in 1963.

Other-Wells in the Floridan aquifer owned by the Florida State Forestry Service, Florida Board of Parks and Historic Monuments, and the U.S. Department of Agriculture, all located in the vicinity of Olustee, supply water for domestic, public, and agricultural uses.

\section{SUMMARY}

Ground water from porous limestone, sand, and shell aquifers is the principal source of water supplies in Baker County. The formations penetrated by water wells range in age from Lake City Limestone of middle Miocene age to Recent sands and clays.

Ground water in Baker County occurs in three aquifers: (1) the water-table aquifer, (2) shallow artesian aquifer, and (3) the Floridan aquifer.

The water-table aquifer consists of surficial sand beds within the upper Miocene or Pliocene and Pleistocene and Recent deposits. This 
aquifer ranges from about 10 to 50 feet in thickness and is recharged by local rainfall.

The shallow artesian aquifers occur in discontinuous sand, shell, and limestone beds within the Hawthorn Formation and the upper Miocene or Pliocene deposits. The thickness and depth of these aquifers varies throughout the county but generally range from 10 to 50 feet in thickness and from 70 to 380 feet below land surface. The shallow artesian aquifers are recharged locally by downward percolation from the water table or from shallower secondary artesian aquifers.

The Floridan aquifer which occurs in the limestones of Eocene age, in the Suwannee Limestone, and limestone beds in the Hawthorn Formation is the greatest potential source of ground water in Baker County. The top of the Floridan aquifer in Baker County ranges from less than 50 to more than 350 feet below sea level. The aquifer is about 750 to 1,000 feet thick. Relatively impermeable layers within the Lake City and Avon Park Limestones may separate the lower part of the aquifer into thin, water-bearing zones.

Piezometric maps show that the water in the Floridan aquieer moves radially away from Baker County toward areas of discharge. In eastern Baker and Bradford counties and western Nassau, Duval, and Clay counties, much of the water moves toward discharge areas in Duval and Nassau counties.

Water from the water-table and shallow artesian aquifers is less mineralized and softer than water from the Floridan aquifer. However, the iron content of water from the water-table and shallow artesian aquifers is generally higher than water from the Floridan aquifer. Although the water from the Floridan aquifer is more mineralized, the chemical quality is adequate for domestic, stock, agricultural, and most industrial purposes. Analyses of water from the Floridan aquifer show there has been a slight increase in the mineral content in recent years.

Most domestic and farm water supplies in Baker County are obtained from the water-table and shallow artesian aquifers. The larger water users in the county obtain water from the Floridan aquifer.

At present there is relatively little development of the ground-water supplies in Baker County. Future industrial development and population growth in the county will require a much greater development of the ground-water resources, particularly from the Floridan aquifer. This aquifer is capable of supplying sufficient quantities of good quality water provided the development of the aquifer is based on a sound water management policy. Because the Floridan aquifer extends throughout all of northeast Florida and southeast Georgia, the development of this aquifer in adjacent areas will affect and be affected to some extent by development in Baker County. 


\section{REFERENCES}

tpplin, E. R. (see Applin, P. L.)

Applin. P. L.

1944 (and Applin, E. R.) Regional subsurface stratigraphy and structure of Florida and southern Georgia: Am. Assoc. Petroleum Geologists Bull., v. 28, no. 12, p. 1673-1753.

Black, A. P. 1951

(and Brown, Eugene) Chemical character of Florida's waters1951: Florida State Board of Conserv., Div. Water Survey and Research, Paper 6.

Brown, Eugene (see Black, A. P., and Cooper, H. H., Jr.)

Cooke, C. W.

1945 Geology of Florida: Florida Geol. Survey Bull. 29.

Cooper, H. H., Jr.

1953 (and Kenner, W. E., and Brown, Eugene) Ground water in central and northern Florida: Florida Geol. Survey Rept. Inv. 10.

Results of transmissibility tests in Duval and Nassau Counties: U.S. Geol. Survey open-file release, Tallahassee, Florida.

Kenner, W. E. (see Cooper, H. H., Jr.)

Leve, G. W. 1966

Ground water in Duval and Nassau Counties, Florida: Florida Geol. Survey Rept. Inv. 43.

Pride, R. W.

1958

Interim report on surface-water resources of Baker County, Florida: Florida Geol. Survey Inf. Circ. 20.

Puri, H. S.

1953

Zonation of the Ocala Group in peninsular Florida (abs.): Jour. Sed. Petrology; v. 23.

1951 Stratigraphy and zonation of the Ocala Group: Florida Geol. Survey Bull. 38 .

Stringfield, V. T. 19.36

Artesian water in the Florida peninsula: U.S. Geol. Survey WaterSupply Paper 773-C.

1966 Artesian water in tertiary limestone in the southeastern states: Geol. Survey Prof. Paper 517.

Vermon, R. 0 . 1951

Geology of Citrus and Levy Counties, Florida: Florida Geol. Survey Bull. 33. 